\title{
GREM1 wt Allele
}

National Cancer Institute

\section{Source}

National Cancer Institute. GREM1 wt Allele. NCI Thesaurus. Code C152000.

Human GREM1 wild-type allele is located in the vicinity of $15 q 13.3$ and is approximately $27 \mathrm{~kb}$ in length. This allele, which encodes gremlin-1 protein, plays a role in antagonizing bone morphogenetic protein signaling pathways. Mutation of the gene is associated with hereditary mixed polyposis syndrome 1. 